\title{
Coal Industry Impact on Ants of the Genus Formica (Hymenoptera: Formicidae)
}

\author{
Svetlana Blinova ${ }^{1, *}$, Marina Korchagina $^{1}$, Aleksandra Radosteva $^{1}$, and Tatiana \\ Dobrydina $^{2}$ \\ ${ }^{1}$ Kemerovo State University, Department of Ecology and Nature Management, 650000, 6 Krasnaya \\ st., Kemerovo, Russian Federation \\ ${ }^{2}$ Kemerovo State University, Department of Foreign Languages in Professional Communication, \\ 650000, 6 Krasnaya st., Kemerovo, Russian Federation
}

\begin{abstract}
The peculiarities of the settlement of ants of the genus Formica have been studied at the areas affected by varying degrees of impact made by enterprises of surface (opencast mines) and underground (deep mines) coal hard mining. It has been revealed that Formica ants. str. are the most sensitive to any impact and in overwhelming cases disappear from the contaminated area. On the contrary, the representatives of Serviformica are more environmentally flexible, and are able to occupy areas with an average degree of contamination. However, the density of the settlement and the abundance remain low. After the cessation of coal mining near opencast mines, the recovery of myrmecofauna occurs more rapidly (7-10 years) than near deep mines (more than 50 years). The higher the degree of contamination of the area, the lighter the colour of the ants. The proportion of insect larvae in the Formica rufa food sharply increases in the contaminated area.
\end{abstract}

\section{Introduction}

It is known that under anthropogenic impact not only the ecological but also the taxonomic structure of biocenosis changes, both in general and in separate groups [for example, 1-2]. This is also fully applied to myrmecocomplexes. Thus, the study of the territory near Sredneuralsk copper plant in Russia has revealed that the area with the average impact of emissions has the richest species composition and number of ants [3]. The increasing urbanization has no less impact: the studies of the Warsaw myrmecocomplexes have shown that the increase in species richness occurs closer to green zones (parks, forests) [4]. In general, in the territory of cities, urban forests, and gardens, there is a depletion of the species composition of ants [5-7]. Particularly sensitive ants in the temperate climate of the northern hemisphere appear to be the ants of the genus Formica, which form the basis of the myrmecocomplexes of terrestrial ecosystems. In this case, the ants are sensitive to various types of impacts. For example, in the forests of Western Siberia, the distribution of the

\footnotetext{
* Corresponding author: $\underline{\text { sv blinova@mail.ru }}$
} 
Formica polyctena nests depends on the intensity of the recreational load [8]. In addition, intensive industrial development leads to the reduction in the number of anthills F. rufa by $66.5 \%$ over 5 years [9]. In conditions of high contamination of the nesting area near metallurgical production plants in Finland, a decrease in the relative abundance of some Formica s. str. compared with uncontaminated areas has been recorded. The volume of nesting mounds of red forest ants in a contaminated area is $34 \%$ lower than in relatively clean areas, and their morphological features do not change [10].

In general, urbanization accelerates the process of budding and the emergence of a large number of small nests of representatives of Formica s. str. [11].

A special form of impact is industrial emissions. As shown in our previous works [1213], the reactions of ants to gaseous and solid emissions differ. The results of long-term observations of myrmecocomplexes in conditions of underground coal mining impact are known [14]. However, the issue of the impact of different types of coal-industry enterprises on myrmecocomplexes in the same natural conditions has not been studied. Therefore, the purpose of this work is to show the impact of different coal mining methods on the state of the ants' settlements of the genus Formica as the basis of the regional myrmecofauna.

\section{Materials and Methods}

The studies were conducted from 1996 to 2017 on the territory of the Kuznetsk coal basin (Kemerovo Region, Russia). The coal industry is the main economic activity of the region. Coal is taken in two ways: surface (opencast mines) and underground (deep mines) coal hard mining. In the past 10 years, the number of opencast mines sharply increased, and, on the contrary, a significant number of deep mines closed, which increased the technogenic load on adjacent cenosis.

The collection of all the material was carried out using the standard myrmecological methods: 5 -10 test sites $(5 * 5 \mathrm{~m}$ in size) were laid out on the area (table 1$)$. The areas of the coal industry enterprises impact were selected based on the distance from the emission sources: 0-1.3 km - an area of strong impact of industrial emissions on biocenosis; 1.31-6 $\mathrm{km}$ - an area of average impact; $6.1 \mathrm{~km}$ and further - an area of weak impact [13].

All the deep mines studied and one opencast mine are located in the forest-steppe zone, the second opencast mine is in the forest zone. Therefore, the relevant areas were used as a control in 30-45 km from the considered emission sources located against the wind rose.

In addition, we studied the phenotypic variability of ants of the genus Formica in the sites located in the areas of different impact of coal industry enterprises using the example of F. rufa and F. cunicularia. These species were selected as the most common subgenera, respectively, Formica s. str. and Serviformica. At the same time, the former is widely distributed in natural areas, the second one, on the contrary, is in the areas prone to high and medium anthropogenic load. Following AV Gilev et al. [15], we adopted the scheme of phenotypic variations developed for red forest ants. This scheme is based on the number and position of pigment spots, forming a pattern on the head and chest (pronotum, mesonotum and epinotum) of working specimens. To study phenotypic variability from each anthill, at least 100 specimens of ants were taken. Since it is known that the colour of working ants depends on their size (large ants are lighter coloured on average, than small ones) [15], so an alignment procedure was performed, so that in the samples being compared, workers of different size classes were represented with the same frequency whenever possible.

Additionally, there were made the observations of the foraging activity of ants at the beginning of each hour for $10 \mathrm{~min}$. on all stern trails from 9 am to $21 \mathrm{pm}$. In this case, the number of ants with prey, crossing the control line towards the nest, was marked. 
Table 1. Characteristics of the studied areas.

\begin{tabular}{|c|c|c|c|}
\hline $\begin{array}{l}\text { Area } \\
\text { Name }\end{array}$ & $\begin{array}{c}\begin{array}{c}\text { Pollution } \\
\text { level }\end{array} \\
\end{array}$ & $\begin{array}{c}\text { Projective } \\
\text { grass cover, } \%\end{array}$ & Notes \\
\hline \multicolumn{4}{|c|}{ Places in coal mining zone } \\
\hline $\operatorname{Pr} 1$ & High & 40 & $\begin{array}{l}50 \% \text { of the territory covered with a } \\
\text { layer of } 5 \mathrm{~cm} \text { of coal dust }\end{array}$ \\
\hline $\operatorname{Pr} 2$ & High & 50 & $\begin{array}{l}\text { Technological dumps formed in } \\
1960-1980\end{array}$ \\
\hline $\operatorname{Pr} 3$ & Average & $50-70$ & \\
\hline $\operatorname{Pr} 4$ & Average & 85 & \\
\hline $\operatorname{Pr} 5$ & Low & 95 & \\
\hline $\operatorname{Pr} M$ & Low & $90-95$ & Control \\
\hline \multicolumn{4}{|c|}{ Areas in the impact zone of opencast mines } \\
\hline Ke 1 & High & $35-50$ & $\begin{array}{l}\text { Age of formation of the area for the } \\
\text { period of the study (hereinafter) } 7 \\
\text { years }\end{array}$ \\
\hline $\operatorname{Ke} 2$ & Average & $50-70$ & 15 years \\
\hline Ke 3 & Low & $80-100$ & 30 years \\
\hline $\mathrm{Kb} 1$ & High & $25-30$ & 15 years \\
\hline $\mathrm{Kb} 2$ & Average & $50-70$ & 15 years \\
\hline $\mathrm{Kb} 3$ & Low & $40-50$ & 30 years \\
\hline
\end{tabular}

At the same time, the systematic position of the prey caught by the ants was recorded (up to the detachment, class). To assess the selectivity of predatory activity of ants, biocenotic samples (BCS) were collected at each site of the study according to standard methods: for the study of chortobionts, the entomological netting method was used in 10 series with 10 strokes per series. To collect dendrobionts, a white linen was placed under the canopy of the tree and bushes. To collect herpetobionts, the method of soil samples was used with a $25 \times 25 \mathrm{~cm}$ frame.

To record the Serviformica subgenus nests, the areas were inspected; if necessary, the soil was scrabbled. When finding a nest, no work was conducted in diameter of $0.2-0.25$ $\mathrm{m}$.: this is the conventional territory occupied by one family. As a measure of abundance, the nest density was used, calculated for one test site. To record Formica's ants. str., there was laid a route length of about $2 \mathrm{~km}$ in such a way that it passed through all the major plant associations of the selected biotope. All the nests within the sight, usually a $12 \mathrm{~m}$ wide strip $( \pm 6 \mathrm{~m})$ were recorded. All the received material was processed in Microsoft Excel 2016 and Statistica v.6.0. For numerical values, the mean values for the study time \pm standard deviation are given. All measurements were performed with the MBS-9 binocular.

\section{Results and discussion}

In the territory under consideration, the genus Formica forms the basis of almost all myrmecocomplexes: 21 species from the found 50 species of 10 genera in Kemerovo 
region belong to this genus. As a result of the conducted investigations in the territory of the affected coal mining enterprises and in a relatively clean zone, the nests of representatives of two subgenera of the genus Formica were found: 5 species of Formica $\mathrm{s}$. str. (F. aquilonia Yarr, F. polyctena Forst., F. rufa L., F. lugubris, F. pratensis Retz.) and 4 species of Serviformica (F. fusca L., F. cunicularia Latr., F. rufibarbis F., F. subpilosa Ruzs.). All species, except F. aqiulonia, do not form large clusters.

\subsection{Species composition and density of nests}

Long-term observations of model sites at different distances from coal enterprises (opencast and deep mines) made it possible to reveal that in the territories located in close proximity to the built up coal storages or opencast mines, the ants disappear during the first growing season. However, the settlement of such areas occurs in different ways, which, in our opinion, is due, first of all, to the method of mining and the ongoing reclamation of used and being used land. Thus, the studies of the impact of coal deep mines on myrmecocomplexes revealed an inverse correlation $(\mathrm{r}=-0.68$ at $\mathrm{p}<0.05)$ between the distance from coal storages, trunks and the number of species. In the most contaminated areas, ants of this genus were not found. The only exception discovered by us was the F. rufa anthill, located under the birch (Betula pendula) near the shaft from 30 to $80 \mathrm{~cm}$ high in different years of observation.

From the genus Formica, the species of the subgenus Serviformica, primarily F. fusca and F. cunicularia, are adapted to the habitat in the area of average impact of coal industry. It is in this area, the maximum density of their nests was marked: up to 0.8 nests $/ 25 \mathrm{~m}^{2}$. On average, the density of settlements of this subgenus during the years of observation was 0.5 \pm 0.2 nests $/ 25 \mathrm{~m}^{2}$.

Only in the area of weak impact and in the control, settlements Formica s. str. were registered. Here the maximum density of nests was recorded: up to 1-2 nests per $100 \mathrm{~m}$ of routing. As the degree of anthropogenic load increases, Formica s. str. species disappear; the number of Serviformica ants' nests increases (Fig. 1).

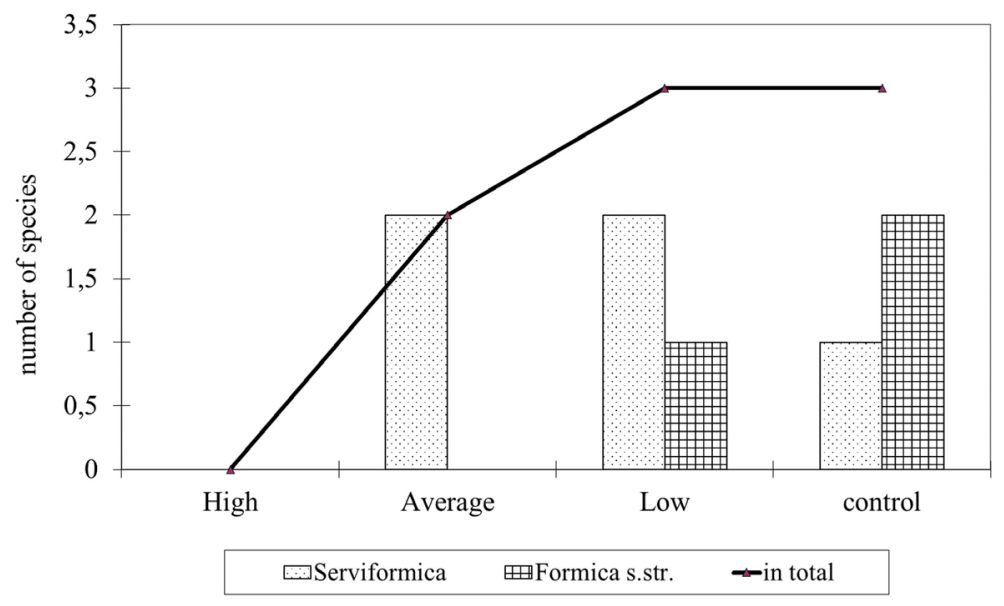

Fig. 1. Species richness of Formica subgenera depending on the distance to the coal deep mine and the impact of coal dust (generalized for areas with the same degree of impact). Characteristics of the areas are presented in Table 1.

When deep coal mining is terminated, ants F. fusca are the first to appear within 2-3 years, then - F. cunicularia. However, our five-year observations of the being closed and 
closed mines revealed only single nests. The low recovery rate may be connected with the absence of a "green window", i.e. some reserve territory, from which the ants could be resettled. All investigated deep mines in the conditions of Kuzbass are located in the city.

It is known that in Italy the species richness of the various genera Formicidae depends on the age of the dumps [16], which fully corresponds to the results we have obtained both in general for species richness and in the genus under consideration. In particular, in the forest zone there is a quasi-adaptive type of formation of dumps and reactions of the studied genus to coal dust. Thus, in comparatively young dumps (area Ke 1), formed 7-10 years ago, a relatively high species diversity ( 6 species) with a settlement density of 0.75 nests $/ 25$ $\mathrm{m}^{2}$ was recorded (everywhere without taking into account Formica s.str.). Three species among them were representatives of the subgenus Serviformica. With the increase in the age of the dumps (area Ke 2), the decrease of all parameters was recorded: 5 species and 0.45 nests $/ 25 \mathrm{~m}^{2}$, respectively, and only nests of F. rufibarbis. In the control, there was an increase again: we found representatives of 4 species (2 - Serviformica and 2 - Formica).

In the forest-steppe zone, the formation of myrmecocomplexes of the dumps occurs somewhat differently (non-adaptive type): the number of species and the density of the settlement increase with the age of the dump. Minimum values recorded for dumps under 15 years (area $\mathrm{Kb} 1$ ) are three species of ants, including F. cunicularia; average density of settlements is 0.3 nests $/ 25 \mathrm{~m}^{2}$. The maximum values are in the control $(8$ species, 1.9 nests $/ 25 \mathrm{~m}^{2}$ and only 2 Formica species). It is remarkable that on the dumps older than 15 years, the density of the settlement sharply increases during 2-5 years, and then quickly decreases again, approaching the control.

The nests of F. aquilonia were found only in old areas and in the control. The only nest of F. subpilosa was recorded on the 7-year-old dump of the forest zone.

It has been revealed that the most adaptable to inhabit the dumps of opencast mines are representatives of the subgenus Serviformica, which populate the dumps 7-10 years after their formation. It must be noted that such changes are typical for areas that have undergone biological remediation. However, our studies of deep mine dumps, which were not recultivated,have shown that the first settlement of ants of the genus Formica (F. fusca) is recorded only after 50 years of existence.. Rise in the age of dumps leads to increasing the number of nests of this subgenus, reaching a maximum density on 30-year-old dumps. Representatives of the subgenus Formica s. str. (F. aquilonia, F. pratensis and F. lugubris) were found only in natural surroundings. However, individual workers of these species were recorded on the dumps older than $30-35$ years.

\subsection{Ethological aspects}

Directly in the area of deep mines, we observed the behavior of the ants F. rufa. It is necessary to note that in comparison with the anthills located in a relatively clean area, the former has a much smaller fodder area: it is limited to 10 birches planted in two rows. At the same time, during the observation period, the total length of the forage roads was sharply reduced by 2-3 times with increasing both coal mining and recreational impact (mowing and cutting the crowns of the birches) in this area.

A study of the foraging activity and the food preferences of F. rufa in the area of opencast mines' impact and in the relatively clean area has shown that the principal groups of small invertebrates, which are used as protein food, remain unchanged. So in all the cases representatives of the order Diptera are predominant. However, in the control in the food of ants, the representation of this order is $13 \%$ higher than in the biocenotic sample. On the contrary, in the impact area of the deep mine, it is almost 2 times lower.

It should be noted that the share of larvae in both BCS does not exceed 5\%. At the same time, in food F. rufa, the share exceeds the indicators by 3-3.5 times. This proves the 
selectivity in prey, regardless of the abundance of certain groups of invertebrates and the degree of impact of the coal industry. Nevertheless, in the area affected by the opencast mines, the larvae of insects in food occupy the second place; in the control - only the fourth.

In a relatively clean area, the representatives of the Coleoptera (18.2\%) and Hymenoptera (17.2\%) groups occupy a significant place in food, which exceeds the biocenotic sample by more than 2 times. On the contrary, the data from the area of impact show practically a correspondence in the percentage composition either in the food of the ants or in the BCS of these orders.

\subsection{Phenotypic variability}

The studies of the phenotypic variability of two species F. cunicularia and F. rufa have been carried out to determine the coal enterprises impact on the colour of ants. It has been shown that the change in the colour of the pronotum F. cunicularia is the most indicative sign; more often a light colour is found. The head of $\mathrm{F}$. cunicularia in most cases is painted in phene 3 . The colour of the mesonotum varies from completely light to completely dark, but a light phene remains the main one. A similar situation is observed when studying the colour of the epinotum. For mesonotum and epinotum, a direct correlation between the colour and the phene of the head and pronotum is marked.

The analysis of the phenotypes of F. cunicularia has shown that the size of the ants is practically unchanged, and, on average, their morphs are lighter than for F. rufa from the same area. This is especially obvious when comparing materials from dumps of opencast mines and natural biocenosis. A direct correlation between colour darkening and sizes of working individuals and the age of dumps was found $(r=0.61$ at $p<0.05)$ that may reflect the adaptation to the succession processes in these ecosystems.

However, our studies of the distribution of various phenotypes of F. rufa throughout the studied territory of Kuznetsk Basin have shown a general tendency of increasing the frequency of occurrence of ants with dark head and mezonotum phenes from north to south. At the same time, the frequency of dark phenes of pronotum decreases from north to south. An increase in the frequency of occurrence of dark mesonotum phenes from north to south is observed, and the frequency of the ants F. rufa with a light epinotum remains unchanged throughout the investigated territory.

\section{Conclusion}

Thus, any degree of anthropogenic impact on landscapes or biocenosis almost immediately affects the species composition of ants and their shape, and the size of the nest. The most sensitive species are the subgenera Coptoformica, and Formica s. str. The most stable ones, inhabiting areas affected by anthropogenic load, are the subgenus Serviformica. No species can withstand a high recreational load. In general, when the technogenic load increases (dumps of opencast mines, the proximity of shafts and coal storages), ants of the genus Formica become lighter than in natural conditions. In conditions of exposure to coal dust, ants prefer more affordable protein food: the proportion of insect larvae increases by 3.5 times compared with the control. It has been revealed that the most adaptable to inhabit the dumps of coal enterprises are representatives of the subgenus Serviformica, which populate the dumps during the first 10 years after its formation. Populating the rock dumps near deep mines is slower: the first Serviformica nests were recorded only 50 years after the formation of the dump. A direct correlation between the colour darkness and the size of working individuals and the age of the dumps has been marked, which may reflect the adaptation to the succession processes in these landscapes. 


\section{References}

1. E. L. Jones, S. R. Leather, Eur. J. Entomol., 109, 463478 (2012)

2. G. A. Evdokimova, I.V. Zenkova, Eurasian Soil Science, 36:8, 872-877 (2003)

3. E. Belskaya, A. Gilev, E. Belskii Environmental Science and Pollution Research, 24:11, 10768-10777 (2017)

4. P.Ślipiński, M. Źmihorski W. Czechowski, Eur. J. Entomol., 109, 197-206 (2012)

5. K. Vepsalainen, B. Pisarski, Animals in urban environment (Polish Academy of Sciences, Krakow, 1998)

6. J. D. Majer, K. R. Brown, J .R. Soc. West. Aust., 69, 13-17 (1987)

7. T. Yamaguchi, Entomol. Science. 8:1, 17-25 (2005)

8. N.M. Bugrova, J. I. Reznikova Mem. Zool., 44, 13-19 (1990)

9. W. T. Szczepanski, T. Podkowka Sylwan., 127:5, 35-44 (1983)

10. T. Eeva, J. Sorvari, V. Koivunen, Environmental Pollution. 132:3, 533-539 (2004)

11. K. Vepsalainen, Wourenrinne Mem. Zool., 29, 191-202 (1978)

12. S.V. Blinova, Russian Journal of Ecology, 39:2, 148-150 (2008)

13. S. Blinova, T. Dobrydina, IOP Conf. Series: Earth and Environmental Science, 115, 012035 (2018)

14. S. Blinova, T Dobrydina, E3S Web of Conferences, 21, 02011 (2017)

15. A. V. Gilev, A. V. Mershchiev, D. S. Malyshev, Entomological Review, 95:8, 941946. (2015)

16. L. Ottonetti, L. Tucci, G. Santini, Restoration Ecology, 14:1, 60-66 (2006) 